\title{
Primary producers and production in Hornsund and Kongsfjorden - comparison of two fjord systems
}

\author{
Zofia T. SMOŁA ${ }^{1,2}$, Agnieszka TATAREK ${ }^{1}$, Józef M. WIKTOR ${ }^{1}$, \\ Józef M.W. WIKTOR Jr. ${ }^{1}$, Anna KUBISZYN ${ }^{1}$ and Jan M. WĘSŁAWSKI ${ }^{1 *}$ \\ ${ }^{1}$ Institute of Oceanology Polish Academy of Science - Marine Ecology Department, \\ ul. Powstańców Warszawy 55, 81-712 Sopot, Poland \\ $<$ zosiasmola@iopan.gda.pl> \\ ${ }^{2}$ Centre for Polar Studies KNOW (Leading National Research Centre), Faculty of Earth Sciences, \\ University of Silesia, ul. Będzinska 60, 41-200 Sosnowiec, Poland \\ *corresponding author <weslaw@iopan.gda.pl>
}

\begin{abstract}
Hornsund and Kongsfjorden are two similar-sized Arctic fjords on the West coast of Spitsbergen. They are influenced by cold coastal Arctic water (Hornsund) and warmer Atlantic water (Kongsfjorden). Environmental conditions affect the timing, quantity, spatial distribution (horizontal and vertical) of spring and summer blooms of protists as well as the taxonomic composition of those assemblages. Here, we compile published data and unpublished own measurement from the past two decades to compare the environmental factors and primary production in two fjord systems. Kongsfjorden is characterized by a deeper euphotic zone, higher biomass and greater proportion of autotrophic species. Hornsund seems to obtain more nutrients due to the extensive seabird colonies and exhibits higher turbidity compared to Kongsfjorden. The annual primary production in the analysed fjords ranges from $48 \mathrm{~g} \mathrm{C} \mathrm{m}^{-2} \mathrm{y}^{-1}$ in Kongsfjorden to $216 \mathrm{~g} \mathrm{C} \mathrm{m}^{-2} \mathrm{y}^{-1}$ in Hornsund, with a dominant component of microplankton (90\%) followed by macrophytes and microphytobenthos.
\end{abstract}

Key words: Arctic, Spitsbergen, primary production, environmental conditions, fjords.

\section{Introduction}

Arctic Ocean is surrounded by continents that partially extend over shelf areas, and these are the most productive parts of the Arctic. Arctic shelf areas are also much more productive than the terrestrial areas, so most of the fresh biogenic matter produced in the Arctic is of marine origin $\left(6.4 \mathrm{Pg} \mathrm{y}^{-1}\right.$ versus $0.8 \mathrm{Pg} \mathrm{y}^{-1}$, respectively; Geider et al. 2001). 
The first broad assessment of the Arctic marine primary production was published by Subba Rao and Platt (1984). These authors demonstrated the productivity in the shelf waters versus the deep, oligotrophic Central Arctic Basin. Subba Rao and Platt estimates were followed by those of Gosselin et al. (1997) and Arrigo et al. (2008). More recent data were published by, Olli et al. (2007), Hill et al. (2013), Matrai et al. (2013) and Fernández-Méndez et al. (2015). Primary production in the Barents Sea shelf was studied by, Sakshaug (2004) and Loeng et al. (2005), and primary production across the entire Arctic shelf was studied by Pabi et al. (2008), whereas primary production in the Arctic Marginal Ice Zone (MIZ) has been reported by, Sakshaug and Skjoldal (1989), Falk-Petersen et al. (2000), Ratkova and Wassmann (2002) and Wassmann et al. (2006). Recently, the use of a modelling approach has been more common for the presentation of primary production in the Arctic (e.g., Wassman et al. 2006; Popova et al. 2012). As the Arctic itself presents a huge logistical challenge, Arctic fjords are often suggested as a research option because they are more accessible and can be used as model areas (Syvitski et al. 1987). Hornsund and Kongsfjorden are fjords of West Spitsbergen, studied extensively with regard to the marine ecosystem over the past two decades (see reviews in Hop et al. (2002) and Svendsen et al. (2002)). Marine ecosystem studies in Kongsfjorden started in 1960, when Digby (1961) first published observations on the microplankton, while marine ecological observations in Hornsund started at the end of the 1970s (e.g., Węsławski et al. 1988; Eilertsen et al. 1989). Further studies concerning primary production and phytoplankton communities in Kongsfjorden and Hornsund are shown in Table 1.

The aim of this study is to review the published (Table 1) and archival unpublished data on the primary production in Hornsund $\left(77^{\circ} \mathrm{N}\right)$ and Kongsfjorden $\left(79^{\circ} \mathrm{N}\right)$, which are known for their different levels of exposure to the increasing inflow of Atlantic Waters (AW) (Walczowski and Piechura 2011). We aim to demonstrate how the primary producers and their performance may differ in the two examined fjords.

\section{Study area}

Hydrological parameters. - The West Spitsbergen coast faces an overwhelming influence of Atlantic Waters (AW), as the West Spitsbergen Current (WSC) (Walczowski and Piechura 2011). AW brings from the south, relatively warm $\left(2\right.$ to $4^{\circ} \mathrm{C}$ and even $10^{\circ} \mathrm{C}$ during summer) and saline (>34.65 PSU) waters (Svendsen et al.2002; Cottier et al. 2005). This current follows the deeper part of the Fram Strait and often enters Kongsfjorden and warms its environment (Svendsen et al. 2002 ; Fig. 1). A recent increase in northward heat transport with AW ranges from 28 to 70 terawatts (Cisewski et al. 2003; Schauer et al. 


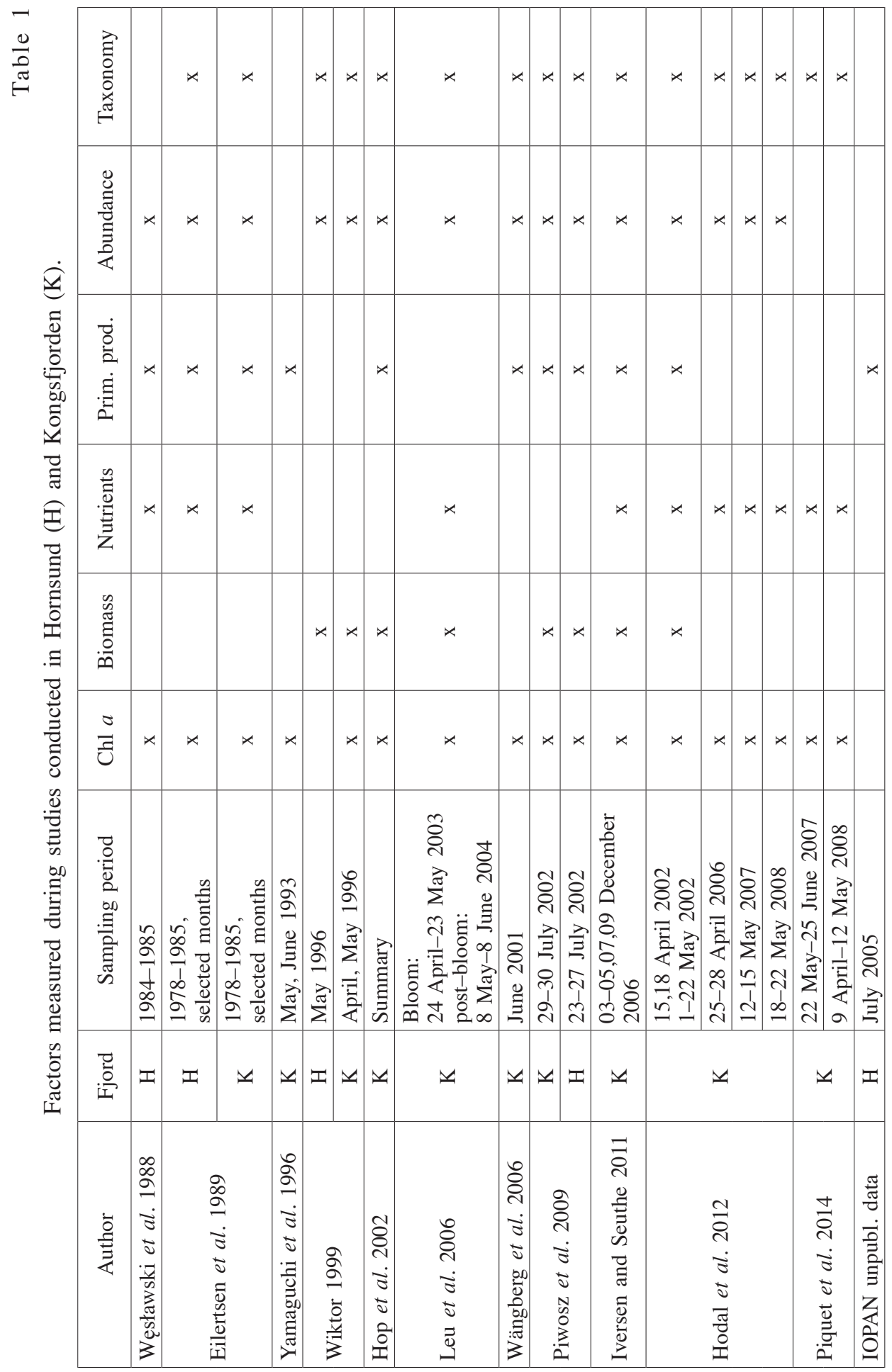




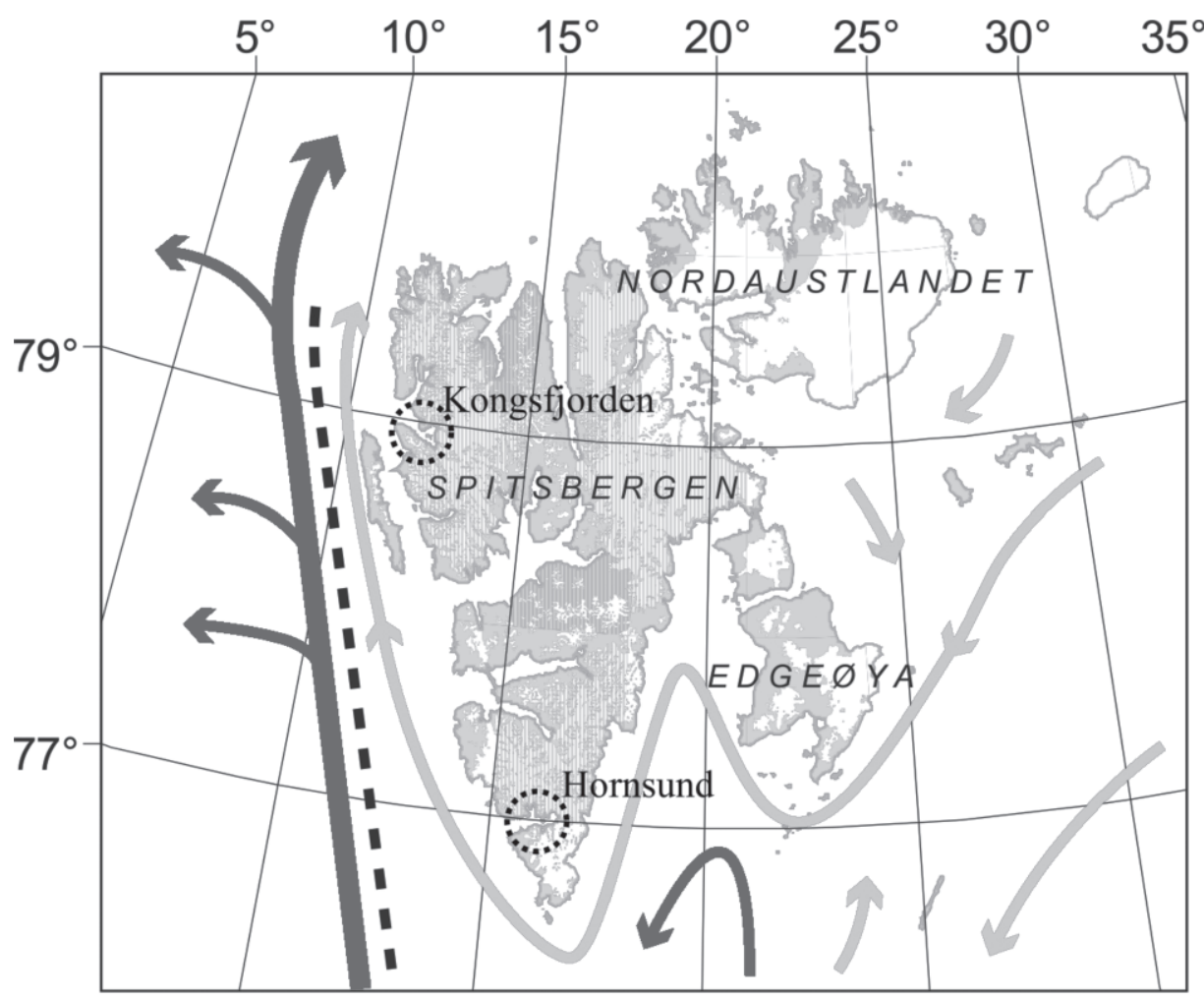

Fig. 1. Currents influencing the West Spitsbergen coast and locations of the fjords. Dark grey line marks the West Spitsbergen Current (Atlantic Water), light grey line marks the Sørkapp Current (coastal Arctic Water) and dotted line marks the Arctic Front (modified from Svendsen et al. 2002).

2004; Walczowski et al. 2005). This heat influx warms adjacent waters and land and increases vapour content, resulting in cloudiness that affects the light conditions during the growth season.

Hornsund is under the influence of cold, less saline coastal Arctic waters $\left(\mathrm{T}<0^{\circ} \mathrm{C}, 34.3<\mathrm{S}<34.7 \mathrm{PSU}\right.$ ) of Barents Sea origin (Skagseth et al. 2008). These waters flow northward along the shelf of the southwest coast of Spitsbergen as the Sørkapp Current, temporarily entering the fjords of the southwest Spitsbergen coast (Swerpel 1985; Cottier et al. 2005). In some years, the Sørkapp Current carries remnants of pack ice from the Barents Sea together with ice-associated diatoms (Hegseth 1992). The simultaneous inflow of Atlantic or Arctic waters through the mouth of the fjord and runoff of fresh and turbid water from the glaciers result in strong horizontal gradients of temperature, salinity and light along the fjord's axis. All of these factors impact the phytoplankton assemblages (Keck et al. 1999; Piwosz et al. 2009). A summary of the relevant physical properties of the discussed fjords is provided in Table 2. 
Table 2

Characteristics of environmental and biological drivers in Hornsund and Kongsfjorden.

\begin{tabular}{|c|c|c|c|c|}
\hline Driver & Hornsund & Kongsfjorden & Units & References \\
\hline Fast ice & $\begin{array}{l}36 \% \text { of the area } \\
\left(112 \mathrm{~km}^{2}\right)\end{array}$ & $\begin{array}{l}3 \% \text { of the area } \\
\left(6 \mathrm{~km}^{2}\right)\end{array}$ & & $\begin{array}{l}\text { IO PAN unpu- } \\
\text { blished data }\end{array}$ \\
\hline $\begin{array}{l}\text { Annual sea surface } \\
\text { temperature range }\end{array}$ & -1.7 to 6 & -1.4 to 12 & ${ }^{\circ} \mathrm{C}$ & $\begin{array}{c}\text { IO PAN data, } \\
\text { Swerpel 1985; } \\
\text { Walczowski and } \\
\text { Piechura } 2011\end{array}$ \\
\hline Salinity & $34.2(28-34.5)$ & $34.4(30-35)$ & PSU & IO PAN data \\
\hline $\begin{array}{l}\text { Spring incident } \\
\text { PAR }\end{array}$ & $\begin{array}{l}18.1 \pm 17.8 \text { to } \\
30.7 \pm 19.0\end{array}$ & $\begin{array}{c}21.4 \pm 14.0 \text { to } \\
29.9 \pm 7.0\end{array}$ & $\begin{array}{l}\text { Einstein· } \\
\mathrm{m}^{-2 \cdot} \cdot \mathrm{d}^{-1}\end{array}$ & $\begin{array}{l}\text { NASA GES } \\
\text { DISC } \\
\text { Mean for } \\
2004-2014\end{array}$ \\
\hline $\begin{array}{l}\text { Summer incident } \\
\text { PAR }\end{array}$ & $19.3 \pm 2.7$ to $28.7 \pm 3.8$ & $\begin{array}{c}24.7 \pm 9.7 \text { to } \\
31.1 \pm 11.3\end{array}$ & $\begin{array}{l}\text { Einstein· } \\
\mathrm{m}^{-2 \cdot \mathrm{d}^{-1}}\end{array}$ & $\begin{array}{l}\text { NASA GES } \\
\text { DISC } \\
\text { Mean for } \\
\text { 2004-2014 } \\
\end{array}$ \\
\hline $\begin{array}{l}\text { Euphotic zone } \\
\text { (1\% PAR) }\end{array}$ & 9.56 & 16.21 & $\mathrm{~m}$ & $\begin{array}{l}\text { IO PAN data, } \\
\text { Sagan and } \\
\text { Darecki unpubli- } \\
\text { shed data }\end{array}$ \\
\hline $\begin{array}{l}\text { Spring nutrient } \\
\text { concentrations }\end{array}$ & $\begin{array}{l}\text { Nitrates - no data } \\
\text { Phosphates to } 0.3 \\
\text { Silicate to } 1.0\end{array}$ & $\begin{array}{l}\text { Nitrates to } 11.3 \\
\text { Phosphates } \\
\text { to } 0.83 \\
\text { Silicate to } 6.0\end{array}$ & $\mu \mathrm{mol} \cdot 1^{-1}$ & $\begin{array}{c}\text { Hegseth and } \\
\text { Tverberg 2013; } \\
\text { Węsławski et al. } \\
1988 ; \\
\text { Hodal et al. } \\
2012 \\
\end{array}$ \\
\hline $\begin{array}{l}\text { Summer nutrient } \\
\text { concentrations }\end{array}$ & $\begin{array}{l}\mathrm{NO}_{2} \text { to } 0.23 \\
\mathrm{NO}_{3} \text { to } 1.96 \\
\mathrm{NH}_{4} \text { to } 2.49 \\
\mathrm{PO}_{4} \text { to } 0.31 \\
\text { Silicate to } 6.0\end{array}$ & $\begin{array}{c}\mathrm{NO}_{2} \text { to } 0.29 \\
\mathrm{NO}_{3} \text { to } 0.67 \\
\mathrm{NH}_{4} \text { to } 0.93 \\
\text { Silicate to } 1.9\end{array}$ & $\mu \mathrm{mol} \cdot 1^{-1}$ & $\begin{array}{c}\text { Eilertsen } \\
\text { et al. 1989; } \\
\text { Węsławski } \\
\text { et al. 1988; } \\
\text { Hodal } \text { et al. } \\
\text { 2012; } \\
\text { Zaborska } \text { et al. } \\
\text { unpublished data }\end{array}$ \\
\hline $\begin{array}{l}\text { Pelagic euphotic } \\
\text { zone } \\
(0-20 \mathrm{~m} \text { depth })\end{array}$ & 277 & 188 & $\mathrm{~km}^{2}$ & $\begin{array}{l}\text { www.iopan.gda. } \\
\text { pl/game/visual }\end{array}$ \\
\hline $\begin{array}{l}\text { Volume of } \\
\text { euphotic pelagic } \\
\text { zone in summer }\end{array}$ & 2.8 & 3 & $\mathrm{~km}^{3}$ & $\begin{array}{l}\text { www.iopan.gda. } \\
\text { pl/game/visual, } \\
\text { Sagan and } \\
\text { Darecki unpubli- } \\
\text { shed data } \\
\end{array}$ \\
\hline $\begin{array}{l}\text { Area of seabed } \\
\text { within euphotic } \\
\text { zone } \\
\text { (hard bottom \%) }\end{array}$ & $25(24 \%)$ & $50(30 \%)$ & $\mathrm{km}^{2}$ & $\begin{array}{l}\text { www.iopan.gda. } \\
\text { pl/game/visual }\end{array}$ \\
\hline
\end{tabular}


Sea ice. - Sea ice plays an important role in Arctic marine ecosystems during the formation of spring blooms of sea-ice associated algae (Hop et al. 2002; Arrigo et al. 2008; Leu et al. 2015). Through the melting period (late spring and summer), the margin of drifting ice pack with algae is an area of prolonged growth of sympagic autotrophs in areas of retreating sea ice. In autumn and winter, during the formation of fast ice in inner fjord basins, pelagic protists are incorporated into the ice; this, along with the advent of spring, initiates an ice algae bloom (Wiktor 2015).

In Hornsund, the fast ice starts to form in the innermost basins in late October and, with frequent breakups in the meantime, usually lasts until late May (Gorlich and Stepko 1992; Węsławski et al. 1993). Over the past decade, the fast ice extent has been limited to the innermost basins of Hornsund (personal observations). The sea ice pack, drifting with the Sørkapp Current from Storfjorden and the Barents Sea, occasionally enters Hornsund and may remain until July (Styszyńska and Kowalczyk 2007; Styszyńska and Rozwadowska 2008; Styszyńska 2009). The formation of fast ice was also a regular phenomenon in Kongsfjorden in the past, but in recent years, the fast ice has been forming only in the inner, most sheltered bay (Nicolaus et al. 2003; Hop et al. 2006; Gerland et al. 2008; Dieckmann et al. 2010; Berge et al. 2015), and compared to Hornsund, it covers a much smaller part of the fjord surface (Table 2).

Photosynthetically active radiation (PAR) and water transparency. - The total solar radiation at high latitudes due to the elevation angle of the Sun is negative for 104 days at $77^{\circ} \mathrm{N}$ (Hornsund) and 116 days at $79^{\circ} \mathrm{N}$ (Kongsfjorden), creating strong seasonality, with a few months of darkness (Fig. 2). Regarding the period from April to August, the photosynthetically active radiation doses are similar but slightly higher in Kongsfjorden (Table 2; Figs 3-4). Both fjords are characterized by strong underwater light gradients from the glacier fronts towards the fjord mouth. The substantial impact of glacier meltwater can result in high amounts of mineral suspension, restricting the depth of the euphotic zone in summer (Lydersen et al. 2014). During spring, when the glacier melt rate decreases, the main limiting factor is fast ice with snow on top. The snow has extremely high attenuation coefficients, causing a reduction in the irradiance in the top-most layer of water to $0.2-5 \%$ of incident PAR (Sakshaug et al. 1994). In summer, the euphotic zone thickness can range from $1 \mathrm{~m}$ to $35 \mathrm{~m}$ in both fjords (Halldal and Halldal 1973; Sagan et al. 1993; Bischof et al. 1998; Sagan and Darecki unpublish data; IOPAN data). On average, Hornsund has more turbid waters than Kongsfjorden in summer; hence, its euphotic zone is approximately 60\% thinner (Table 2; Sagan and Darecki IOPAN data).

Nutrients. - The nutrients depleted during the spring bloom and summer are restored during the dark period through intensive vertical mixing, upwelling 


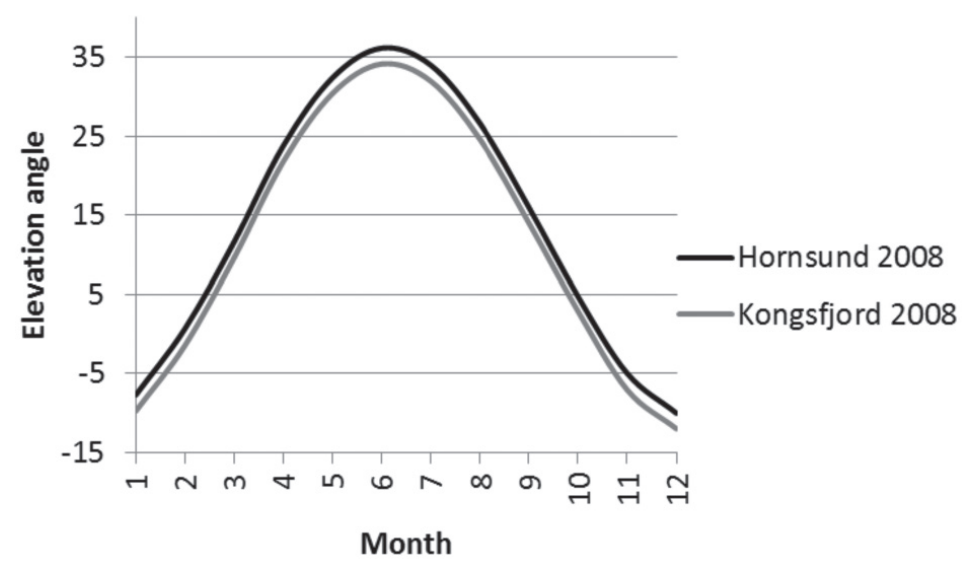

Fig. 2. Sun elevation angle for Hornsund and Kongsfjorden.

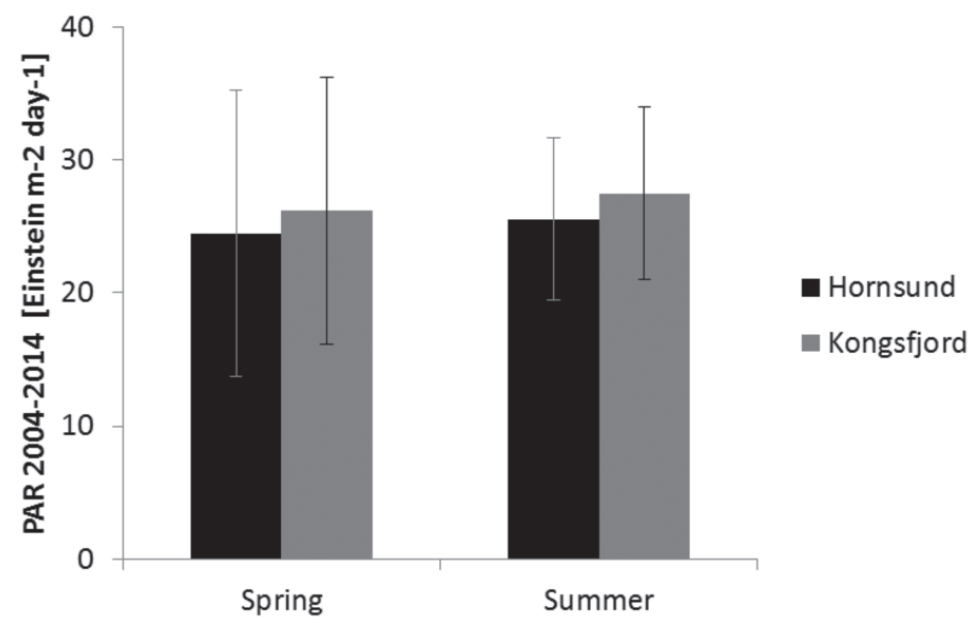

Fig. 3. Mean daily spring and summer PAR flux for the decade 2004-2014 in Hornsund and Kongsfjorden (NASA Goddard Earth Sciences Data and Information Services Center-GES DISC. Accessed data obtained 01 May 2015).

or convection at high latitudes (Olli et al. 2002). This process is magnified during winter because the pycnocline formed by glacier meltwater reduces the supply of nutrients from deeper water layers. There is apparently a strong local nutrient source - seabird colonies located by the seashore - as the biomass of seabirds in Hornsund is threefold higher compared to Kongsfjorden (Węsławski et al. 2009). This is reflected in the higher $\mathrm{N}$ content in Hornsund compared to Kongsfjorden (Table 2). Outside of ammonia, the nutrient concentrations are at similar levels in both fjords, with an apparent summer decrease. No depletion 


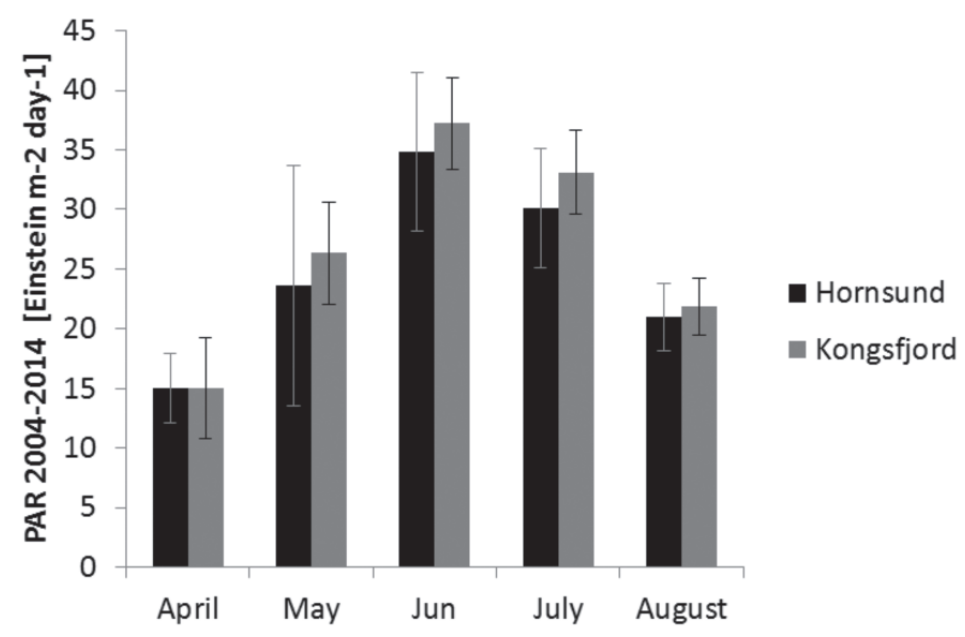

Fig. 4. Monthly average of PAR value for the decade 2004-2014 in Hornsund and Kongsfjorden (NASA Goddard Earth Sciences Data and Information Services Center-GES DISC. Accessed data obtained 1 August 2015).

of silicate in the fjords as a result of the strong freshwater runoff has been noted (Eilertsen et al. 1989; Wang et al. 2009; Hegseth and Tverberg 2013; IOPAN data; Table 2).

\section{Primary producers}

Microplankton. - Arctic planktonic protists account for over 2106 species (Poulin et al. 2011). Hop et al. (2006) reported a total of 148 taxa, of which Bacillariophyta (45\%) and Dinophyta (11\%) were the dominant groups in Kongsfjorden (Table 3). Protist biodiversity varies with the seasons, e.g., for spring in Kongsfjorden, Hop et al. (2002) reported more than 60 microplankton taxa, most of which were diatoms, while Wiktor (1999) reported 35 taxa. Protist communities have been more frequently investigated during the summer season. Biodiversity seems to be higher in summer, and thus Keck et al. (1999) reported 50 taxa, Okolodkov et al. (2000) 40, Hop et al. (2002) more than 130, Wiktor and Wojciechowska (2005) 39, and Kubiszyn et al. (2014) 162. Most of the species are of Atlantic and cosmopolitan origin, whereas only $31(21 \%)$ are considered to be Arctic or boreal-Arctic species (Hasle and von Quillfeldt 1996).

Common species in open water during May include the haptophyte Phaeocystis pouchetii (max. abundance $12^{9} \mathrm{cells} \cdot \mathrm{m}^{-3}$ ) and diatoms of the genera Chaetoceros, Thalassiosira and Fragilariopsis (Eilertsen et al. 1989; Hop et al. 2002; Hodal et al. 2012). Among the dinoflagellates, members of the genera 
Table 3

Primary producers in Hornsund and Kongsfjorden. Range of microplankton biomass based on highest values recorded during reviewed studies.

\begin{tabular}{|c|c|c|c|}
\hline Group/parameter & Hornsund & Kongsfjorden & References \\
\hline Microplankton taxa number & 84 & 148 & $\begin{array}{l}\text { Wiktor and Wojciechowska } \\
\text { 2005; } \\
\text { Okolodkov et al. } 2000 ; \\
\text { Hop et al. } 2002\end{array}$ \\
\hline $\begin{array}{l}\text { Spring microplankton bio- } \\
\text { mass range } \\
{\left[\mathrm{mg} \mathrm{C} \mathrm{m}^{-3}\right]}\end{array}$ & 85.0 & $5-336$ & Wiktor 1999; Leu et al. 2006 \\
\hline $\begin{array}{l}\text { Summer microplankton bio- } \\
\text { mass range } \\
{\left[\mathrm{mg} \mathrm{C} \mathrm{m}^{-3},\left(\mathrm{mg} \mathrm{C} \mathrm{m}^{-2}\right)\right]}\end{array}$ & $\begin{array}{c}100 \\
(2100)\end{array}$ & $\begin{array}{c}32 \\
(1850-2770)\end{array}$ & $\begin{array}{c}\text { Piwosz et al. 2009; } \\
\text { Iversen and Seuthe } 2011\end{array}$ \\
\hline Ice algae species number & $28^{*}$ & 23 & $\begin{array}{c}\text { * data from nearby Sassenfjord } \\
\text { (Spitsbergen) Węsławski et al. } \\
\text { 1993; Wiktor } 1999\end{array}$ \\
\hline $\begin{array}{l}\text { Microphytobenthos taxa } \\
\text { number }\end{array}$ & no data & 89 & Woelfel et al. 2010 \\
\hline $\begin{array}{l}\text { Microphytobenthos biomass } \\
{\left[\mathrm{mg} \mathrm{Chl} a \mathrm{~m}^{-2}\right]}\end{array}$ & no data & 317 & Woelfel et al. 2010 \\
\hline $\begin{array}{l}\text { Macroalgae biomass } \\
\text { [tonne C] }\end{array}$ & 1282 & 1936 & $\begin{array}{l}\text { calculated from Kruss et al. } \\
\text { 2008; IOPAN unpublished data; } \\
\text { hard bottom area after Duarte } \\
\text { (unpublished data) }\end{array}$ \\
\hline Macroalgae taxa number & 49 & 76 & $\begin{array}{c}\text { Węsławski et al. 2010; Latała } \\
\text { and Florczyk 1989; Hop et al. } \\
\text { 2012, Fredriksen et al. 2014; } \\
\text { Tatarek et al. 2012; } \\
\text { http://www.iopan.gda.pl/ wiktor/ } \\
\text { macroalgae/index.html }\end{array}$ \\
\hline
\end{tabular}

Protoperidinium and Gymnodinium have been commonly found (Eilertsen et al. 1989; Wiktor 1999).

The dominance of microplankton species in summer assemblages in Kongsfjorden is variable across studies. Piwosz et al. (2009) reported a major contribution of diatoms to the phytoplankton biomass (especially Pseudonitzschia seriata), but Hop et al. (2002) and Okolodkov (2000) indicate the occasional occurrence of diatoms in Kongsfjorden summer assemblages and the domination of dinoflagellates (Protoperidinium spp., Gymnodinium spp. and Gyrodinium spp., max. cell no. $\left.0.6 \cdot 10^{9} \mathrm{~m}^{-3}\right)$, unidentified flagellates $(<7 \mathrm{um})$ and the chrysophyte Dinobryon balticum ( $\max .3 .5 \cdot 10^{9}$ cells $\mathrm{m}^{-3}$ ). Further, in addition to the diatom 
Pseudonitzschia seriata, Piwosz et al. (2009) indicated dinoflagellates as the second most important contributor to the total phytoplankton biomass in Kongsfjorden (autotrophic dinoflagellates, e.g., Scrippsiella trochoidea and Neoceratium arcticum). They contributeded over $60 \%$ of the biomass in the subsurface layers, in addition to Gymnodinium arcticum in some parts of the fjord. The maximal biomass values in Kongsfjorden vary from $15 \mathrm{~g} \mathrm{C} \mathrm{m}^{-2}$ in spring to $7.9 \mathrm{~g} \mathrm{C} \mathrm{m}^{-2}$ in summer (Table 3; Fig. 5).

In Hornsund, Wiktor and Wojciechowska (2005) identified 84 microplankton taxa (Table 3); however, Wiktor (1999) indicated poor assemblage composition in the water column under the fast ice and in adjacent areas. Eilertsen et al. (1989) recorded an overwhelming abundance of undetermined flagellates, Phaeocystis puchetti and diatoms (especially Fragilariopsis sp. and Chaetoceros socialis) in the spring community in Hornsund. In turn, Piwosz et al. (2009) recorded a great importance of diatom species in phytoplankton assemblages in summer, mostly Chaetoceros socialis, but also those from deeper water, below the euphotic zone, meaning that they were advected from other areas. Nanoflagellates were marked as the second most important contributor to the total phytoplankton biomass. Their contribution was $>20 \%$ of the total phytoplankton biomass in some parts of the fjord and $>80 \%$ of the total protist biomass. The biomass of autotrophic dinoflagellates contributed to no more than $22 \%$, while Cryptomonads contributed up to $40 \%$ of the phytoplankton biomass. There is also a characteristic summer horizontal gradient in the microplankton distribution within the fjord, with flagellates and mixotrophs dominating the turbid waters of the inner basins, while the open outer fjord part is inhabited by larger-sized diatoms and dinoflagellates (Piwosz et al. 2009). The highest reported biomass of microplankton ranged from $2.3 \mathrm{~g} \mathrm{C} \mathrm{m}^{-2}$ in spring (GAME project data) to $2.1 \mathrm{~g} \mathrm{C} \mathrm{m}^{-2}$ in summer (Piwosz et al. 2009; Table 3) and dropped down to single cells observed during the winter dark season (Węsławski et al. 1990; Wiktor 1999; Berge et al. 2015; Błachowiak-Samołyk et al. 2015).

Grazing on microplankton in fjords increases from spring to summer, when the new generation of local herbivorous copepods grows (Kwaśniewski et al. 2010) and large herbivores, such as krill, are advected from the shelf area (Buchholz et al. 2010).

Ice algae. - The first algal bloom in Arctic ice-covered marine areas occurs in the bottom layer of the sea ice. This community develops through three distinct phases in the transition from winter to spring, which is described by Leu et al. (2015). A total of 1027 sympagic protist taxa have been reported from four PanArctic regions (Syvertsen 1991; Poulin et al. 2011). The biomass of ice algae communities is almost exclusively dominated by the genera Nitzschia, Navicula, Pauliella and Fragilariopsis (Gosselin et al. 1997; Riedel et al. 2008; Leu et al. 
A

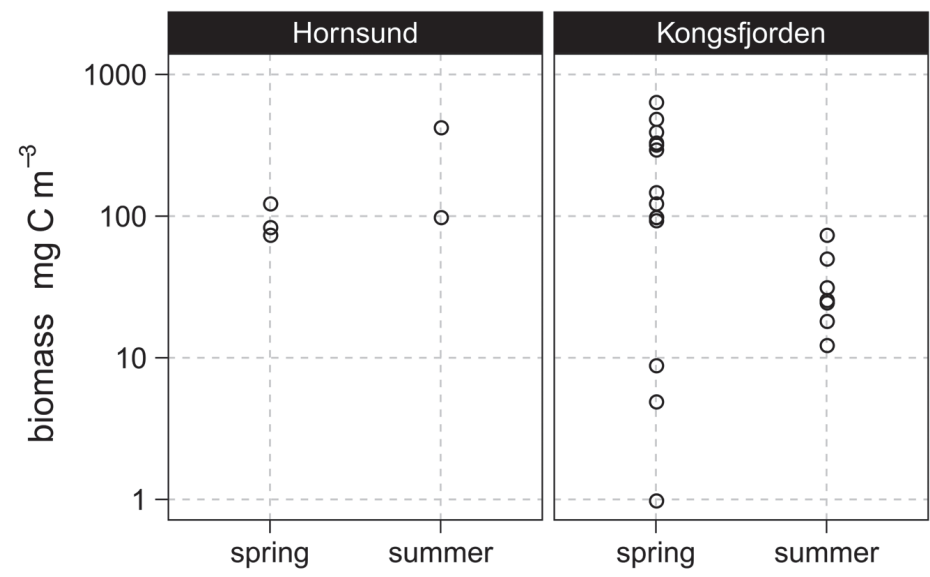

B

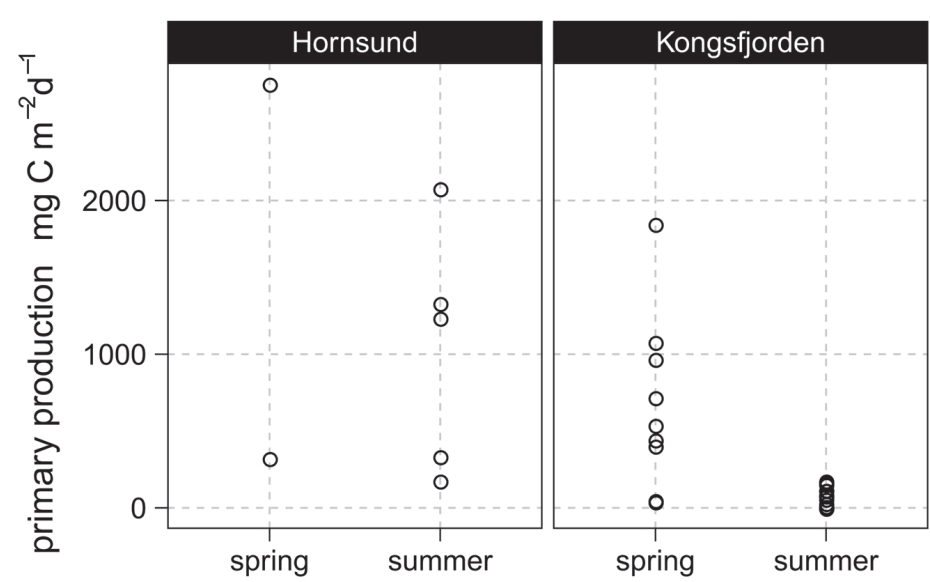

Fig. 5. Range of daily values of biomass (A) and primary production (B) reported across studies during spring and summer in Kongsfjorden and Hornsund (IO PAN data).

2015), which often account for $>90 \%$ of the total algal cell abundance (Smith and Sakshaug 1990; von Quillfeldt 2000; Różańska et al. 2009; Wiktor 2015). The occasional advection of true ice algae from the ice pack is possible in fjords (Wiktor 2015); however, both the diversity and biomass of ice-associated algae in the examined fjords are low. The fast ice contributes little to the diversity and biomass of ice algae; however, several typical ice-associated species have been noted for the Spitsbergen fjords (Węsławski et al. 1993; Wiktor 1999). There are no specific fast ice-related grazers in the fjords, and true sympagic fauna feeding on ice algae rarely enter the examined fjords (op. cit.). 
Microphytobenthos. - Benthic microalgae occur from the upper littoral (splash zone) to the shallow sublittoral, on soft sediment and hard substrates and on large algae. They contribute to the coastal ecosystem not only as primary producers but also as sediment stabilizers (Decho 2000; Wiktor unpublished data). The microphytobenthos also has an important ecological role as a food source for ciliates, meiofauna (mainly Nematoda, Kinorhyncha and Harpacticoida) and some macrofauna (small species of gastropods and amphipods). Although the importance of benthic microalgae has been recognized and studied for decades around the globe, the role of the polar microphytobenthos, except that of Greenland (Rysgaard et al. 1999; Glud et al. 2007), has been given much less attention. Data from Spitsbergen were collected by Woelfel et al. (2010) and Wiktor (unpublished data); in Kongsfjorden, from 29 to 89 species were reported, with biomass attaining $317 \mathrm{mg} \mathrm{Chl} a \mathrm{~m}^{2}$ (Woelfel et al. 2010; Sevilgen unpublished data).

Macroalgae. - Arctic macroalgae are abundant and diverse, with 194 species from Svalbard (Gulliksen et al. 1999) and 76 species from Kongsfjorden having been recorded (Fredriksen et al. 2014). In Hornsund, 49 species have been noted (Table 3). Their occurrence ranges from the upper littoral to the shallow sublittoral, limited by the euphotic zone (kelp to some $25 \mathrm{~m}$ and coralline algae to $50 \mathrm{~m}$ depth). There are reports of the deep occurrence of macrophytes in Kongsfjorden (Meyer and Sweetman 2015); however, this is likely to be the effect of the transport of stones with attached algae by sea currents and gravity rather than a natural phenomenon. There is also a consensus that macrophytes are increasing in biomass and vertical occurrence with diminishing ice cover and increasing temperature (Węsławski et al. 2010; Hop et al. 2012).

Tatarek et al. (2012) showed that macroalgae (mostly kelps) within a $0.65 \mathrm{~km}^{2}$ area in the euphotic zone are potentially capable of reaching $988 \mathrm{~T}$ of biomass in Hornsund. A quite similar situation was found in Kongsfjorden, where Kruss et al. (2008) revealed that in a plot of $1.04 \mathrm{~km}^{2}$ in the euphotic zone, brown algae are potentially capable of gaining $1825 \mathrm{~T}$ of biomass (Table 3). Duarte (unpublished data) assumes that macrophytes in Kongsfjorden occur on 30\% of the bottom area restricted by the 5-25 m depth contour in the outer basin and $10 \%$ in the inner basin - these percentages reflect the share of hard bottom. The difference $(20 \%)$ between these two fjords in biomass value may be explained by the physical conditions occurring in these fjords, such as less ice scouring and more extensive hard bottom shallow areas (Węsławski et al. 2010; Drewnik et al. 2016; Bartsch et al. 2016; Moy unpublished data).

Seaweeds are important not only as primary producers that supply a great amount of fixed carbon to fjords but also because they provide a substrate for benthic organisms (Lippert et al. 2001; Włodarska-Kowalczuk et al. 2009). Grazers living on macroalgae are rare in Spitsbergen, and the only confirmed 
species is the sea urchin Strongylocentrotus droebachiensis. On the other hand, decaying macroalgal detritus is an important component of the sublittoral benthic food web in both fjords (Legeżyńska et al. 2014; Renaud et al. 2015).

\section{Results}

Primary production: measurements and estimates. - A summary of pelagic primary production can be found in Table 4 . The data are presented as ranges of the highest values reported in the studies in Table 1. To standardize the pelagic biomass data as the biomass of organic carbon (Fig. 5a), a conversion from $\mathrm{Chl} a$ to $\mathrm{C}$ was applied (with the assumption of a 1:50 ratio of Chl $a$ to $\mathrm{C}$, adopted from Wiktor 1999). The annual pelagic primary production calculated

Table 4

Range of spring and summer Chl $a$ and pelagic primary production and estimates of primary production in $(\mathrm{H})$ Hornsund and $(\mathrm{K})$ Kongsfjorden.

\begin{tabular}{|c|c|c|c|c|}
\hline Driver & Hornsund & Kongsfjorden & Units & References \\
\hline $\begin{array}{l}\text { Spring } \\
\text { Chlorophyll } a \\
\text { range }\end{array}$ & $1.5-2.5$ & $0.18-13.0$ & $\mathrm{mg} \mathrm{Chl} a \mathrm{~m}^{-3}$ & $\begin{array}{l}\text { H - Eilertsen et al. } 1989 \text {; } \\
\text { Węsławski et al. } 1988 \\
\text { K - Iversen and Seuthe } \\
\text { 2011; Hegseth and Tverberg } \\
2013\end{array}$ \\
\hline $\begin{array}{l}\text { Summer } \\
\text { Chlorophyll } a \\
\text { range }\end{array}$ & 8.61 & $0.25-1.5$ & $\mathrm{mg} \mathrm{Chl} a \mathrm{~m}^{-3}$ & $\begin{array}{l}\mathrm{H} \text { - Piwosz et al. } 2009 \\
\mathrm{~K} \text { - Eilertsen } \text { et al. } 1990 \\
\text { Piwosz et al. } 2009\end{array}$ \\
\hline $\begin{array}{l}\text { Pelagic spring } \\
\text { primary production } \\
\text { range }\end{array}$ & $\begin{array}{c}0.32-2.77 \\
0.43-0.32 *\end{array}$ & $\begin{array}{l}9.72-44.40 \\
2.23 *\end{array}$ & $\begin{array}{l}\operatorname{g~C~m}^{-2} \cdot \mathrm{d}^{-1} \\
\mathrm{~g} \mathrm{C} \mathrm{m}^{-3} \cdot \mathrm{d}^{-1 *}\end{array}$ & $\begin{array}{l}\text { H - Eilertsen et al. } 1989 ; \\
\text { Eilertsen } \text { et al. } 1989 * \\
\mathrm{~K} \text { - Iversen and Seuthe } \\
\text { 2011; Hodal et al. } 2012 \text {; } \\
\text { Hodal et al. } 2012 *\end{array}$ \\
\hline $\begin{array}{l}\text { Pelagic summer } \\
\text { primary production } \\
\text { range }\end{array}$ & $\begin{array}{c}2.08 \\
0.15^{*}\end{array}$ & $\begin{array}{c}0.03-0.169 \\
0.003-0.019^{*}\end{array}$ & $\begin{array}{l}\mathrm{g} \mathrm{C} \mathrm{m} \mathrm{m}^{-2} \cdot \mathrm{d}^{-1} \\
\mathrm{~g} \mathrm{C} \mathrm{m}^{-3} \cdot \mathrm{d}^{-1 *}\end{array}$ & $\begin{array}{l}\mathrm{H} \text { - Piwosz et al. } 2009 ; \\
\text { Eilertsen } \text { et al. } 1989^{*} ; \\
\mathrm{K} \text { - Eilertsen et al. } 1989 ; \\
\text { Eilertsen et al. } 1989^{*} ; \\
\text { Piwosz et al. } 2009^{*}\end{array}$ \\
\hline $\begin{array}{l}\text { Microplankton } \\
\text { annual primary } \\
\text { production range }\end{array}$ & 48.07 & 216.43 & $\mathrm{~g} \mathrm{C} \mathrm{m}^{-2} \cdot \mathrm{y}^{-1}$ & $\begin{array}{l}\text { calculated from reviewed } \\
\text { data }\end{array}$ \\
\hline $\begin{array}{l}\text { Macroalgae annual } \\
\text { primary production }\end{array}$ & $2.0-20 *$ & $2.0-20$ & $\mathrm{~g} \mathrm{C} \mathrm{m}^{-2} \cdot \mathrm{y}^{-1}$ & $\begin{array}{l}\text { Gómez et al. 2009; } \\
\text { adopted from Kongsfjorden* }\end{array}$ \\
\hline Microphytobenthos & No data & $2-14$ & $\mathrm{~g} \mathrm{C} \mathrm{m}^{-2} \cdot \mathrm{y}^{-1}$ & Woelfel et al. 2012 \\
\hline
\end{tabular}


basing on daily primary production values is shown in Fig. 5b, using data obtained from the investigations reported in Table 1. For this purpose, the data were standardized from hour ${ }^{-1}$ to day ${ }^{-1}(24 \mathrm{~h})$. The annual carbon production was roughly estimated with the assumption of a 180-day growing season in the Arctic. The growth season begins in spring (April) and lasts until September (e.g., Iversen et al. 2011). Thus, in calculations we assumed 60 days of spring and 120 days of summer (Table 4). Values were calculated for the euphotic layer of each fiord (Fig. 6). The mean euphotic zone (1\% PAR) depth in summer was taken from Sagan and Darecki (unpublished data) as $9 \mathrm{~m}$ in Hornsund and $16 \mathrm{~m}$ in Kongsfjorden. According to this assumption, the total volume ranged from 2.8 to $3 \mathrm{~km}^{3}$, respectively. While these values were used for the estimates of annual primary production of the phytobenthos (macroalgae and microphytobenthos) specific to the surface of the bottom of the euphotic zone in each fjord, the euphotic area of the seabed (0-20 m depth) was taken as $25 \mathrm{~km}^{2}$ in Hornsund and $50 \mathrm{~km}^{2}$ in Kongsfjorden (Table 2). Values of microphytobenthic and macrophytobenthic primary production were adopted from the measurements and estimates shown below.

Microphytobenthos. - Woelfel et al. (2010) showed that the microalgae in a research area of $3.7 \mathrm{~km}^{2}$ of sandy and muddy substrate in the euphotic zone are potentially capable of reaching $76-1900 \mathrm{~kg} \mathrm{C} \mathrm{y}^{-1}$ of biomass and that

A

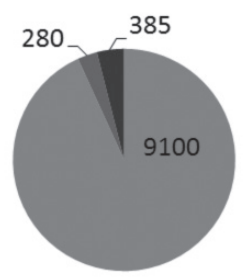

B

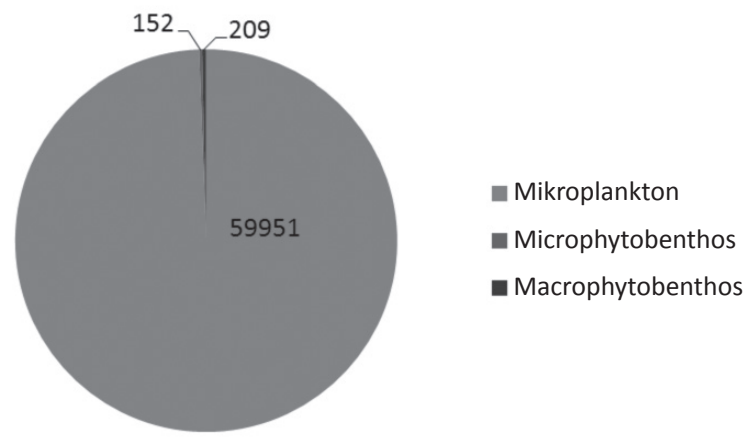

Fig. 6. Organic carbon production [tonne $\mathrm{C}^{-1}$ ] in the eutrophic zone of Kongsfjorden (A) and Hornsund (B). 
the summer period of primary production provides $19 \mathrm{~g} \mathrm{C} \mathrm{m}^{-2} \cdot \mathrm{y}^{-1}$ (Table 3). The estimates calculated by Glud and Rysgaard (2007) in Greenland during the summer season showed that the microbenthic community of Young Sound, which is dominated by diatoms, accounts for up to $40 \%$ of the total benthic primary productivity, with a mean production rate of $10 \mathrm{~g} \mathrm{C} \mathrm{m}^{-2} \cdot \mathrm{y}^{-1}$ (Rysgaard et al. 1999).

Macrophytes. - Seaweeds can reach high primary productivity in some areas, which can be comparable to or even higher than that of phytoplankton (Gómez et al. 2009). Arctic macroalgal primary productivity reaches up to $20 \mathrm{~g} \mathrm{C} \mathrm{m}^{-2} \cdot \mathrm{y}^{-1}$ (estimated for the brown algal species Laminaria solidungula). However, depending on the species, it may be only 1-2 $\mathrm{g} \mathrm{C} \mathrm{m}^{-2} \cdot \mathrm{y}^{-1}$ (for Saccharina latissima, Gómez et al. 2009). Benthic micro- and macroalgae in Arctic coastal areas may potentially provide $28 \%$ and $13 \%$ of the net primary production, respectively (Gómez et al. 2009).

Benthic macroalgae accounted for approximately $20 \%$ of the local net primary production in Greenland's Young Sound (Glud and Rysgaard 2007). For the purposes of this paper, we assume, following Gómez et al. (2009), that the macroalgal primary production in Hornsund and Kongsfjorden may range from 2.0 to $20 \mathrm{~g} \mathrm{C} \mathrm{m}^{-2} \cdot \mathrm{y}^{-1}$ and that the production rate depends on the surface of the seabed in the euphotic zone.

Microplankton. - With 48.07-216.43 $\mathrm{g} \mathrm{C} \mathrm{m}^{-2 \cdot} \mathrm{y}^{-1}$ in Hornsund and Kongsfjorden (Table 4), the primary production and Chl $a$ concentration of the microplankton seem to be higher than that in other Svalbard fjords, e.g., Rijpfjorden (Leu et al. 2011), which is located further north $\left(>80^{\circ} \mathrm{N}\right)$ and is strongly influenced by the Arctic Ocean. Waters directly around the Svalbard archipelago are also less productive than those in the West Spitsbergen fjords. The estimated daily production in the examined fjords is similar to the daily production along the Barents Sea Polar Front (Owrid et al. 2000).

Production rates, biomass and Chl $a$ concentrations in the High Arctic are restricted and inversely correlated to the ice cover, light attenuation, surface mixed layer depth and total mesozooplankton biomass (Gosselin et al. 1997; Owrid et al. 2000).

Production in the Bering Sea and Chukchi Sea estimating from 230 to $>400 \mathrm{~g} \mathrm{C} \mathrm{m}^{-2} \cdot \mathrm{y}^{-1}$ (Sakshaug 2004) or even 576-720 $\mathrm{g} \mathrm{C} \mathrm{m}^{-2} \cdot \mathrm{y}^{-1}$ (Hansell et al. 1993) is considered to be the highest in the Arctic and is significantly higher than in Hornsund and Kongsfjorden. The variation in primary production is well known in the Arctic and is mostly attributed to differences in water masses, ice presence, and nutrient concentrations (Hansell and Goering 1990; Springer and McRoy 1993; Springer unpublished data). The statement about 
different annual primary production in the two fjords is supported by sediment data by Zaborska (unpublished data) and sediment trap data from Grzelak and Głuchowska (unpublished data), who demonstrate higher amounts of organic carbon falling to the Hornsund seabed compared to Kongsfjorden.

\section{Discussion}

The taxonomic structure of the phytoplankton assemblages in the two fjords demonstrated differences between the associations (Wiktor and Wojciechowska 2005), which may be an effect of the lower number of protist investigations in Hornsund. The expected number of taxa might be similar and slightly modified by macroscale hydrological conditions. Hasle and von Quillfeldt (1996) emphasized a high contribution of Atlantic species in Kongsfjorden phytoplankton assemblages. Phytoplankton communities inhabiting West Spitsbergen fjords appear to be more diverse in terms of taxonomic composition than those in open marine waters surrounding the archipelago (Owrid et al. 2000; Hegseth and Sundfjord 2008). Fjord associations are also substantially different from the diatom-dominated Margina Ice Zone (MIZ) blooming assemblages known in the Barents Sea (Olli et al. 2002; Ratkova and Wassmann 2002; Olli et al. 2007), other Arctic shelf areas (Sakshaug 2004), polynyas (Lovejoy et al. 2002), the Central Arctic Basin (where assemblages are dominated by relatively small and often unidentified flagellates), or the coastal waters of western Greenland (Nielsen and Hansen 1999). Kongsfjorden is more diverse in microplankton and macrophytobenthic species than Hornsund due to the advection of Atlantic Waters. The more extensive fast ice in Hornsund does not allow ice species to cope with the diversity of the warmer site.

There is a difference in the seasonal $\mathrm{Chl} a$ concentration between the two fjords (higher in spring and lower in summer in Hornsund compared to Kongsfjorden) (Fig. 5a). In general, Hornsund has higher microplankton primary production rates per unit area and over the whole year, despite the larger volume of the euphotic zone in Kongsfjorden (Fig. 5b). This can be caused by one or a combination of three reasons: lower grazing pressure in Hornsund, higher nutrient supply in Hornsund (seabird colonies, nutrient-rich coastal waters, shallower area with easy mixing), or low nutrient concentrations in the Atlantic Waters of Kongsfjorden (depleted on the way along the West Spitsbergen Currents, too deep to mix easily). In the present situation, the "warmer" fjord shows lower production compared to the colder coastal waters of Hornsund (Fig. 6). The different proportions of autotrophs in the net primary production show that Kongsfjorden experiences an important contribution from non-pelagic autotrophs, while in Hornsund, the share of benthic species is less visible (Fig. 6). 
Primary production in West Spitsbergen fjords is lower than in areas of high productivity, e.g., the Barents Sea, and comparable to other high Arctic fjords. Of the two fjords compared, Hornsund is shallower, less connected with the Atlantic water inflow from the shelf and more ice covered compared to Kongsfjorden. The irradiance, sea surface temperature, and dynamics of the two fjords are comparable. Hornsund is poorer in autotrophic species number. Kongsfjorden on one hand receives more species and biomass from the Atlantic Waters inflow; on the other hand, increased glacial melt and increased turbidity in the inner basins reduce the performance of marine autotrophs. Hornsund will soon became a proper "sund" when the ice barrier bordering it from Storfjorden collapses (Głowacki pers. comm.). This shall increase the presence of coastal, cold water in Hornsund and cause consequent isolation from the warmer shelf waters. It is likely that Hornsund will remain more "local" and cold compared to the atlantification of Kongsfjorden.

Acknowledgements. - This publication was financed by funds from the Leading National Research Centre (KNOW) received by the Centre for Polar Studies for the period 2014-2018 and project NCN (National Research Center in Poland): GAME (Growing of the Arctic Marine Ecosystem) - DEC-2012/04/A/NZ8/00661. The research leading to these results has received funding from the Polish-Norwegian Research Programme operated by the National Centre for Research and Development under the Norwegian Financial Mechanism 2009-2014 in the frame of Project Contract No POL-NOR/199377/91/2014 (GLAERE).

\section{References}

ARRIGO K.R., VAN DiJKEN G. and PABI S. 2008. Impact of a shrinking Arctic ice cover on marine primary production. Geophysical Research Letters 35: L19602.

Bartsch I., PAar M., Fredriksen S., Schwanitz M., Daniel K., Hop H. and Wiencke CH. 2016. Changes in kelp forest biomass and depth distribution in Kongsfjorden, Svalbard, between 1996-1998 and 2012-2014 reflect Arctic warming. Polar Biology 39: 2021.

Berge J., Renaud P.E., Darnis G., Cottier F., Last K., Gabrielsen T.M., Johnsen G., Seuthe L., WęsŁaWski J.M., Leu E., Moline M., Nahrgang J., Søreide J.E., Varpe Ø., LøNNE O.J., DAASE M. and FALK-PETERSEN S. 2015. In the dark: A review of ecosystem processes during the Arctic polar Night. Progress in Oceanography 139: 258-271.

Bischof K., Hanelt D., TÜG H., Karsten U., Brouwer P.E. and WiencKe C. 1998. Acclimation of brown algal photosynthesis to ultraviolet radiation in Arctic coastal waters (Spitsbergen, Norway). Polar Biology 20: 388-395.

BŁachowiak-SamoŁyK K., Wiktor J.M., Hegseth E.N., Wold A., Falk-Petersen S. and KUBISZYN A.M. 2015. Winter Tales: the dark side of planktonic life. Polar Biology 38: 23-36.

BUCHHOLZ F., BUCHHOLZ C. and WĘSŁAWSKI J.M. 2010. Ten years after: krill as indicator of changes in the macro-zooplankton communities of two Arctic fjords. Polar Biology 33: 101-113.

CisEWSKI B., BudÉUS G. and KRAUSE G. 2003. Absolute transport estimates of total and individual water masses in the northern Greenland Sea derived from hydrographic and acoustic Dop- 
pler current profiler measurements. Journal of Geophysical Research: Oceans (1978-2012): 108(C9).

Cottier F., Tverberg V., Inall M., Svendsen H., Nielsen F. and Griffiths C. 2005. Water mass modification in an Arctic fjord through cross-shelf exchange: The seasonal hydrography of Kongsfjorden, Svalbard. Journal of Geophysical Research: Oceans (1978-2012): $110(\mathrm{C} 12)$.

DeCHO A.W. 2000. Microbial biofilms in intertidal systems: an overview. Coastal Shelf Research 20: $1257-1273$.

Dieckmann G., NehrKe G., Uhlig C., Göttlicher J., Gerland S., Granskog M.A., and ThoMAS D.N. 2010. Ikaite $\left(\mathrm{CaCO}_{3} \cdot 6 \mathrm{H}_{2} \mathrm{O}\right)$ discovered in Arctic sea ice. The Cryosphere 4: 227-230.

DiGBY P.S. 1961. The vertical distribution and movements of marine plankton under midnight-sun conditions in Spitsbergen. The Journal of Animal Ecology 30: 9-25.

EILERTSEN H.C., TAASEN J.P. and WęSŁAWSKI J.M. 1989. Phytoplankton studies in the fjords of West Spitsbergen: physical environment and production in spring and summer. Journal of Plankton Research 11: 1245-1260.

Falk-Petersen S., Hop H., Budgell W.P., Hegseth E.N., Korsnes R., LøYning T.B., ØRBÆK J.B., KAWAMURA T. and SHIRASAWA K. 2000. Physical and ecological processes in the marginal ice zone of the northern Barents Sea during the summer melt period. Journal of Marine Systems 27: 131-159.

Fernández-Méndez M., Katlein C., Rabel B., Nicolaus M., Peeken I., Bakker K., Flore H. and Boetius H. 2015. Photosynthetic production in the Central Arctic during the record sea-ice minimum in 2012. Biogeosciences Discussions 12: 2897-2945.

FLORCZYK I. and LATAŁA A. 1989. The phytobenthos of the Hornsund fjord, SW Spitsbergen. Polar Research 7: 29-41.

FREDRIKSEN S., BARTSCH I. and WIENCKE CH. 2014. New additions to the benthic marine flora of Kongsfjorden, western Svalbard, and comparison between 1996/1998 and 2012/2013. Botanica Marina 57: 203-216.

Geider R.J., Delucia E.H., Falkowski P.G., Finzi A.C., Grime J.P., Grace J., Kana T.M., La Roche J., Long S.P., Osborn B.A., Platt T., Prentice I.C., Raven J.A., SchlesinGer W.H., Smetacek V., Stuart V., Sathyendranath S., Thomas R.B., Vogelmann T.C., WILLIAMS P. and WoODWARD F.I. 2001. Primary productivity of planet earth: biological determinants and physical constraints in terrestrial and aquatic habitats. Global Change Biology 7: 849-882.

Gerland S., Renner A.H.H., GodtliebSEN F., Divine D. and LøYNing T.B. 2008. Decrease of sea ice thickness at Hopen, Barents Sea, during 1966-2007. Geophysical Research Letters 35: L06501.

GLUD R. and RYSGAARD S. 2007. The annual carbon budget of Young Sound, NE Greenland. In: S. Rysgaard and R.N. Glud (eds), Carbon Cycling in Arctic Marine Ecosystems: Case Study Young Sound. Meddelelser om Grønland, Bioscience 58: 193-203.

Gómez I., Wulff A., Roleda M.Y., Huovien P., Karsten U., Quartino M.L., Dunton K. and WIENCKE C. 2009. Light and temperature demands of marine benthic microalgae and seaweeds in polar regions. Botanica Marina 52: 593-608.

GORLICH K A. and STEPKO W. 1992. Hydrological phenomena related to sea ice formation and presence in Hornsund, Spitsbergen. In: K.W. Opaliński and R.Z. Klekowski (eds), Landscape, Life World and Man in High Arctic. Instytut Ekologii, Polska Akademia Nauk, Warszawa: 83-92.

Gosselin M., LeVASSEur M., WheEler P.A., Horner R.A. and BoOth B.C. 1997. New measurements of phytoplankton and ice algal production in the Arctic Ocean. Deep-Sea Research II 44: $1623-1644$. 
Gulliksen B., Palerud R., Brattegard T. and Sneli J. (eds) 1999. Distribution of marine benthic macro-organisms at Svalbard (including Bear Island) and Jan Mayen. Research Report for Directorate for Nature Management 4: 148.

HALlDAl P. and HALLDAL K. 1973. Phytoplankton, chlorophyll, and submarine light conditions in Kings Bay, Spitsbergen, July 1971. Norwegian Journal of Botany 20: 99-108.

HANSELL D.A. and GoERING J.J. 1990. Pelagic nitrogen flux in the northern Bering Sea. Continental Shelf Research 10: 501-519.

Hansell D.A., Whitledge T.E. and Goering J.J. 1993. Patterns of nitrate utilization and new production over the Bering-Chukchi shelf. Continental Shelf Research 13: 601-627.

HASLE G.R. and VON QUILLFELDT C.H. 1996. A catalogue of Svalbard plants, fungi, algae and cyanobacteria. Part 8. Marine microalgae. Skrifter-Norsk Polarinstitutt 198: 375-382.

HeGSETH E.N. 1992. Sub-ice algal assemblages of the Barents Sea: species composition, chemical composition, and growth rates. Polar Biology 12: 485-496.

HEGSETH E.N. and SUNDFJORD A. 2008. Intrusion and blooming of Atlantic phytoplankton species in the high Arctic. Journal of Marine Systems 74: 108-119.

Hegseth E.N. and TVERBERG V. 2013. Effect of Atlantic water inflow on timing of the phytoplankton spring bloom in a high Arctic fjord (Kongsfjorden, Svalbard). Journal of Marine Systems 113: 94-105.

Hill V.J., Matrai P.A., Olson E., Suttles S., Steele M., Codispoti L.A. and Zimmerman R.C. 2013. Synthesis of integrated primary production in the Arctic Ocean: II. In situ and remotely sensed estimates. Progress in Oceanography 110: 107-125.

Hodal H., Falk-Petersen S., Hop H., Kristiansen S. and Reigstad M. 2012. Spring bloom dynamics in Kongsfjorden, Svalbard: nutrients, phytoplankton, protozoans and primary production. Polar Biology 35: 191-203.

Hop H., Pearson T., Hegseth E.N., M. Kovacs K.M., Wiencke C., Kwaśniewski S., Eiane K., Mehlum F., Gulliksen B., WŁodarska-KowalczuK M., Lydersen C., WęSŁaWsKi J.M., Cochrane S., Gabrielsen G.W., Leakey R.J.G., LønNe O.J., ZajĄCZKowski M., FALKPetersen S., Kendall M., Wängberg S-Å., Kai Bischof K., Voronkov A.Y., KoVAltchouk N.A., Wiktor J.M., Poltermann M., Di Prisco G., PAPUCCI C. and Gerland S. 2002. The marine ecosystem of Kongsfjorden, Svalbard. Polar Research 21: 167-208.

Hop H., Falk-Petersen S., Svendsen H., Kwaśniewski S., Pavlov V., Pavlova O. and SøREIDE J.E. 2006. Physical and biological characteristics of the pelagic system across Fram Strait to Kongsfjorden. Progress in Oceanography 71: 182-231.

Hop H., WiencKe C., VöGele B. and KovaltchouK N.A. 2012. Species composition, zonation, and biomass of marine benthic macroalgae in Kongsfjorden. Svalbard. Botanica Marina 55: 399-414.

IVERSEN K.R. and SEUTHE L. 2011. Seasonal microbial processes in a high-latitude fjord (Kongsfjorden, Svalbard): I. Heterotrophic bacteria, picoplankton and nanoflagellates. Polar Biology 34: 731-749.

KeCK A. 1999. West Spitsbergen Fjords (Svalbard, Norwegian Arctic): Physical Settings and Sedimentation. The Finnish Environment 263: 58-68.

KeCK A., WikTor J.M., HAPTER R. and NiLSEN R. 1999. Phytoplankton assemblages related to physical gradients in an Arctic glacier-fed fjord in summer. ICES Journal of Marine Science 56: $203-214$.

Kruss A., Blondel P., TĘGOWSKI J., WiKTOR J.M. and TATAREK A. 2008. Estimation of macrophytes using single-beam and multibeam echosounding for environmental monitoring of Arctic fjords (Kongsfjord, West Svalbard Island). Journal of the Acoustical Society of America 123: 3213-3213. 
KUBISZYN A.M., PIwOSZ K. and WIKTOR J.M. 2014. The effect of inter-annual Atlantic water inflow variability on the planktonic protist community structure in the West Spitsbergen waters during the summer. Journal of Plankton Research 36: 1190-1203.

KWAŚNIEWSKi S., GŁUCHOWSKa M., JAKUBAS D., WoJCZULANIS-JAKUBAS K., WALKUSZ W., KARNOWSKY N., BŁACHOWIAK-SAMOŁYK K., CIESEK M. and STEMPNIEWICZ L. 2010. The impact of different hydrographic conditions and zooplankton communities on provisioning Little Auks along the West coast of Spitsbergen. Progress in Oceanography 87: 72-82.

LEGEŻYŃSKA J., KĘDRA M. and WALKUSZ W. 2014. Identifying trophic relationships within the high Arctic benthic community: how much can fatty acids tell? Marine Biology 161: 821-836.

Leu E., FalK-Petersen S., KwaŚniewski S., WulfF A., Edvardsen K. and Hessen D.O. 2006. Fatty acid dynamics during the spring bloom in a High Arctic fjord: importance of abiotic factors versus community changes. Canadian Journal of Fisheries and Aquatic Sciences 63: $2760-2779$

Leu E., Mundy C.J., Assmy P., Campbell K., Gabrielsen T.M., Gosselin M.T., JuUl-PedERSEN T. and GRADINGER R. 2015. Arctic spring awakening - Steering principles behind the phenology of vernal ice algal blooms. Progress in Oceanography 139: 151-170.

Leu E., Søreide J.E., Hessen D.O., FalK-Petersen S. and Berge J. 2011. Consequences of changing sea - ice cover for primary and secondary producers in the European Arctic shelf seas: timing, quantity, and quality. Progress in Oceanography 90: 18-32.

LIPPERT H., IKEN K., RACHOR E. and WIENCKE CH. 2001. Macrofauna associated with macroalgae in the Kongsfjord (Spitsbergen). Polar Biology 24: 512-522.

LOENG H., Brander K., CARMack K.E., Denisenko S., Drinkwater K., Hansen B., Kovacs K., Livingston P., MClaughlin F. and Sakshaug E. 2005. Marine Systems: Arctic Climate Impact Assessment: An Assessment of Consequences of Climate Variability and Change and the Effects of Increased UV in the Arctic Region. Arctic Climate Impact Assessment: 439-538.

Lovejoy C., LEgENDRE L. and PRICE N.M. 2002. Prolonged diatom blooms and microbial food web dynamics: experimental results from an Arctic polynya. Aquatic Microbial Ecology 29: 267-278.

Lydersen C., Assmy P., Falk-Petersen S., Kohler J., Kovacs K.M., Reigstad M., Steen H., Strøm H., SundfJord A., Varpe Ø., WalczowsKi W., WęSŁaWSKi J.M. and ZAJĄCZKOWSKI M. 2014. The importance of tidewater glaciers for marine mammals and seabirds in Svalbard, Norway. Journal of Marine Systems 129: 452-471.

Matrai P.A., Olson E., Suttles S., Hill V., Codispoti L.A., Light B. and Steele M. 2013. Synthesis of primary production in the Arctic Ocean: I. Surface waters, 1954-2007. Progress in Oceanography 110: 93-106.

MEYER K.S. and SWEETMAN A.K. 2015. Observation of a living macroalga at $166 \mathrm{~m}$ in a high Arctic fjord. Marine Biodiversity Records 8: e58-61.

NicOlaUs M., HAAS C. and BAREISS J. 2003. Observations of superimposed ice formation at meltonset on fast ice on Kongsfjorden, Svalbard. Physics and Chemistry of the Earth 28: 1241-1248.

NIELSEN T.G. and HANSEN B.W. 1999. Plankton community structure and carbon cycling off the western coast of Greenland during stratified summer situation. I. Hydrography, phytoplankton and bacterioplankton. Aquatic Microbial Ecology 16: 205-216.

OKolodKov Y.B., HAPTER R. and SEMOVSKI S.V. 2000. Phytoplankton in Kongsfjorden, Spitsbergen, July 1996. Sarsia 85: 1-8.

Olli K., Wassmann P., Reigstad M., Ratkova T.N., Arashkevich E., Pasternak A., MatRAI P.A., KNULST J., TRANVIK L., KLASIS R. and JACOBSEN A. 2007. The fate of production in the central Arctic Ocean-top-down regulation by zooplankton expatriates? Progress in Oceanography 72: 84-113. 
Owrid G., Socal G., Civitarese G., Luchetta A., Wiktor J.M., NÖthig E.M., ANDreassen I., SCHAUER U. and STRASS V. 2000. Spatial variability of phytoplankton, nutrients and new production estimates in the waters around Svalbard. Polar Research 19: 155-171.

PABi S., VAN DiJken G.L. and ARrigo K.R. 2008. Primary production in the Arctic Ocean, 1998-2006. Journal of Geophysical Research 113: C08005.

Piwosz K., Walkusz W., HAPTER R., WieCZOREK P., Hop H. and WikTOR J.M. 2009. Comparison of productivity and phytoplankton in a warm (Kongsfjorden) and a cold (Hornsund) Spitsbergen fjord in mid-summer 2002. Polar Biology 32: 549-559.

Popova E.E., Yool A., Coward A.C., Dupont F., Deal C., Elliott S., Hunke E., Jin M., STEELE M. and ZHANG J. 2012. What controls primary production in the Arctic Ocean? Results from an intercomparison of five general circulation models with biogeochemistry. Journal of Geophysical Research: Oceans (1978-2012): 117(C8).

Poulin M., DAUGBJERG N., Gradinger R., ILYASh L., RATKOVA T. and VON QUILLFELDT C. 2011. The pan-Arctic biodiversity of marine pelagic and sea-ice unicellular eukaryotes: A first-attempt assessment. Marine Biodiversity 41: 13-28.

RATKOVA T.N. and WASSMANN P. 2002. Seasonal variation and spatial distribution of phyto- and protozooplankton in the central Barents Sea. Journal of Marine Systems 38: 47-75.

Renaud P., LOKKen T.S., JoRgensen L.L., Berge J. and JOHNSON B.J. 2015. Macroalgal detritus and food-web subsidies along an Arctic fjord depth-gradient. Frontiers in Marine Science 2: 31 .

Riedel A., Michel C., Gosselin M. and LeBlanc B. 2008. Winter-spring dynamics in sea ice carbon cycling in the coastal Arctic Ocean. Journal of Marine Systems 74: 918-932.

RÓŻAŃSKA M., GOSSELIN M., POULIN M., WiKTOR J.M. and Michel C. 2009. Influence of environmental factors on the development of bottom ice protist communities during the winter-spring transition. Marine Ecology Progress Series 386: 43-59.

RYSGAARD S., NIELSEN T.G. and HANSEN B.W. 1999. Seasonal variation in nutrients, pelagic primary production and grazing in a high-Arctic coastal marine ecosystem, Young Sound, Northeast Greenland. Marine Ecology Progress Series 179: 13-25.

SAGAN S., KowALCZUK P. and ZAJĄCZKOWSKI M. 1993. Optical properties of waters around Svalbard and Franz Josef Land. International Society for Optics and Photonics 2048: 64-72.

Sakshaug E. 2004. Primary and Secondary Production in the Arctic Seas. In: R. Stein and R.W. Macdonald (eds) The organic carbon cycle in the Arctic Ocean. Springer, Berlin, Heidelberg: $57-81$.

SaKshaug E. and SkJOLDAl H.R. 1989. Life at the ice edge. Ambio 18: 60-67.

SaKshaug E., BJøRge A., Gulliksen B., Loeng H. and Mehlum F. 1994. Structure, biomass distribution, and energetics of the pelagic ecosystem in the Barents Sea: a synopsis. Polar Biology 14: 405-411.

Schauer U., Ahrbach E.F., ØSterhus S. and RohardT G. 2004. Arctic warming through the Fram Strait: Oceanic heat transport from 3 years of measurements. Journal of Geophysical Research: Oceans (1978-2012): 109(C6).

Skagseth Ø., FureviK T., Ingvaldsen R., Loeng H., Mork K.A., Orvik K.A. and Ozhigin V. 2008. Volume and heat transports to the Arctic Ocean via the Norwegian and Barents Seas. In: B. Dickson, J. Meincke and P. Rhines (eds), Arctic-subarctic ocean fluxes: defining the role of the northern seas in climate. Springer, Netherlands: 45-64.

SMith W.O.Jr and SAKSHAUg E. 1990. Polar phytoplankton. In: W.O. Smith Jr. (ed.), Polar Oceanography, Part B Chemistry, Biology and Geology. Academic Press, San Diego: 477-525.

SPRINGER A.M. and MCROY C.P. 1993. The paradox of pelagic food webs in the northern Bering Sea-III. Patterns of primary production. Continental Shelf Research 13: 575-599. 
STYSZYŃSKA A. and KowALCZYK M. 2007. Zlodzenie Hornsundu i jego przedpola (SW Spitsbergen) w sezonie zimowym 2005-2006. Problemy Klimatologii Polarnej 17: 147-158.

STYSZYŃSKA A. and ROZWADOWSKA A. 2008. Zlodzenie Hornsundu i jego przedpola (SW Spitsbergen) w sezonie zimowym 2006/2007. Problemy Klimatologii Polarnej 18: 141-160.

STYSZYŃSKA A. 2009. Zlodzenie Hornsundu i jego przedpola (SW Spitsbergen) w sezonie zimowym 2007/2008. Problemy Klimatologii Polarnej 19: 247-267.

Subba Rao D.V. and PlatT T. 1984. Primary production of Arctic waters. Polar Biology 3: 191-210.

SVendsen H., BeszczyńsKa-Möller A., Hagen J.O., Lefauconnier B., TVerberg V., GerLAND S., ØRBÆK JB., BiSCHOF K., PAPUCCI C., ZAJĄCZKOWSKI M., AZZOLINI R., BRULAND O., WincKe C., Winther J.G. and DALlmanN W. 2002. The physical environment of Kongsfjorden-Krossfjorden, an Arctic fjord system in Svalbard. Polar Research 21: 133-166.

SwERPEL S. 1985. The Hornsund fjord: Water Masses. Polish Polar Research 6: 475-496.

SYVERTSEN E.E. 1991. Ice algae in the Barents Sea - types of assemblages, origin, fate and role in the ice-edge phytoplankton bloom. Polar Research 10: 277-287.

SYVITSKI J.P.M., BURRELl D.C. and SKEI J.M. 1987. Fjords: Processes and Products. Springer Science \& Business Media: 379 pp.

TATAREK A., WIKTOR J.M. and KendAll M.A. 2012. The sublittoral macroflora of Hornsund. Polar Research 31: 18900.

VON QUILLFELDT C.H. 2000. Common diatom species in arctic spring blooms: their distribution and abundance. Botanica Marina 43: 499-516.

WalczowsKi W. and Piechura J. 2011. Influence of the West Spitsbergen Current on the local climate. International Journal of Climatology 31: 1088-1093.

WaLcZowski W., Piechura J., Osinski R. and WiecZOREK P. 2005. The West Spitsbergen Current volume and heat transport from synoptic observations in summer. Deep-Sea Research I 52: $1374-1391$.

Wang G., Chaoying G., Wei L.C., CAi M. and He J. 2009. The distribution of picoplankton and nanoplankton in Kongsfjorden, Svalbard during late summer. Polar Biology 32: 1233-1238.

WÄNGBERG S.A., ANDREASSON K.I., GARDE K., GuSTAVSON K., HENRIKSEN P. and REINTHALER T. 2006. Inhibition of primary production by UV-B radiation in an arctic bay-model calculations. Aquatic Sciences-Research Across Boundaries 68: 117-128.

Wassmann P., Slagstad D., Riser C.W. and Reigstad M. 2006. Modelling the ecosystem dynamics of the Barents Sea including the marginal ice zone: II. Carbon flux and interannual variability. Journal of Marine Systems 59: 1-24.

WĘSŁAWSKI J.M., WIKTOR J.JR. and KOTWICKI L. 2010. Increase in biodiversity in the arctic rocky littoral, Sorkappland, Svalbard, after 20 years of climate warming. Marine Biodiveristy 40: $123-130$.

WĘSŁAWSKI J.M., KWAŚNIEWSKI S. and WIKTOR J.M. 1990. Winter in a Svalbard fjord ecosystem. Arctic 44: 115-123.

WĘSŁAWSKI J.M., KWAŚNIEWSKI S., JEZIERSKI J., MOSKAL W. and ZAJĄCZKOWSKI M. 1988. Seasonality in an arctic fiord ecosystem, Hornsund, Spitsbergen. Polar Research 6: 185-189.

WĘSŁAWSKI J.M., KWAŚNIEWSKI S., STEMPNIEWICZ L. and BŁACHOWIAK-SAMOŁYK K. 2006. Biodiversity and energy transfer to top trophic levels in two contrasting Arcitc fjords. Polish Polar Research 27: 259-278.

WĘSŁAWSKI J.M., KWAŚNIEWSKI S., WIKTOR J.M. and ZAJĄCZKOWSKI M. 1993. Observations on the fast ice biota in the fjords of Spitsbergen. Polish Polar Research 14: 331-343.

WIKTOR J.M. 1999. Early spring microplankton development under fast ice covered fjords of Svalbard, Arctic. Oceanologia 41: 51-72.

WIKTOR J.M. 2015. Morskie pierwotniaki Arktyki. Rozprawy i monografie IO PAN 24: 178 pp. 
WiKTOR J.M. and WojCIECHOWSKA K. 2005. Differences in taxonomic composition of summer phytoplankton in two fjords of West Spitsbergen, Svalbard. Polish Polar Research 26: 259-268.

WŁodarska-KowalczuK M., KuKlińsKi P., Ronowicz M., LEgeŻyńsKa J. and Gromisz S. 2009. Assessing species richness of macrofauna associated with macroalgae in Arctic kelp forests (Hornsund, Svalbard). Polar Biology 32: 897-905.

Woelfel J., Schumann R., Peine F., Flohr A., Kruss A., Tęgowski J., Blondel P., Wiencke C. and KARSTEN U. 2010. Microphytobenthos of Arctic Kongsfjorden (Svalbard, Norway): biomass and potential primary production along the shore line. Polar Biology 33: 1239-1253.

Yamaguchi Y., MiYahara T., Matsuda O. and Kudoh S. 1996. Primary production of phytoplankton in high Arctic Kongsfjorden, Svalbard. Memoirs of National Institute of Polar Research. Special Issue 51: 143-151.

Received 23 February 2016

Accepted 2 May 2017 